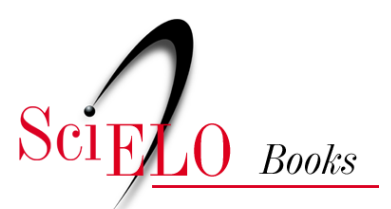

\title{
Histórias do Dr. Giovanni Gazzinelli (novembro de 1999)
}

\author{
Virgínia Schall
}

\section{SciELO Books / SciELO Livros / SciELO Libros}

SCHALL, V. Histórias do Dr. Giovanni Gazzinelli (novembro de 1999). In: Contos de Fatos: histórias de Manguinhos [online]. Rio de Janeiro: Editora FIOCRUZ, 2001, pp. 221-240. ISBN: 97885-7541-614-3. Available from: doi: $10.7476 / 9788575416143.0017$. Also available in ePUB from: http://books.scielo.org/id/hdq6f/epub/schall-9788575416143.epub.

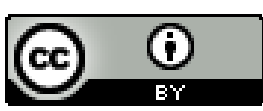

All the contents of this work, except where otherwise noted, is licensed under a Creative Commons Attribution $\underline{4.0 \text { International license. }}$

Todo o conteúdo deste trabalho, exceto quando houver ressalva, é publicado sob a licença Creative Commons Atribição 4.0. 


\section{Histórias do Dr. \\ Giovanni Gazzinelli}

(novembro de 1999)

Como todos os aspectos dos seres vivos são, em última análise, determinados na esfera molecular, foi necessário adquirir a compreensão da molécula da vida para entender a própria vida.

David E. Brody \& Arnold R. Brody

o entrar na sala do Dr. Gazzinelli, alguns quadros e mapas nas paredes
me chamaram a atenção. Um deles é uma composição de quatro Lme chamaram a atenção. Um deles é uma composição de quatro auto-retratos de Rembrandt. Ao identificar o artista, perguntei-lhe se era seu pintor preferido. Dr. Gazzinelli sorriu e me respondeu que não propriamente o pintor, mas um daqueles quadros, com o qual se identificava agora, como disse, já mais velho. Trata-se do último auto-retrato do pintor, datado de 1668, uma extraordinária e penetrante análise que ele fez de si mesmo, bastante diferente do seu mais famoso Auto-Retrato Jurenil, pintado em 1633. Rembrandt costumava pintar de quando em quando um autoretrato, e nesta série foi registrando sua transformação desde moço até os sessenta e poucos anos. Como afirmam os historiadores, o auto-retrato era para Rembrandt um exercício de estilo e investigação, por meio do qual ele buscava em sua própria face e no olhar o sinal do tempo, da paixão, da vida. Segundo afirmam, nos retratos ele registrava a passagem do tempo e as dificuldades do dia-a-dia, uma magnífica e bela reprodução psicológica, de tal perspicácia, que sem dúvida arrebatou o interesse do Dr. Gazzinelli. 
Próximo a Rembrandt, uma fotografia chama a atenção: é o Dr. Gazzinelli ao lado do Papa Paulo VI, numa visita a Roma. Como conta, fora convidado para uma reunião científica na Pontifícia Academia de Ciências do Vaticano, convocada por seu presidente, o Prof. Carlos Chagas. Lembra-se então de uma passagem divertida, e aqui pude perceber a veia humorística e perspicaz do Dr. Gazzinelli, mesmo conhecendo-o há pouco tempo. Conta que no grupo estavam vários outros pesquisadores brasileiros e estrangeiros. Achavam-se todos hospedados num hotel próximo ao Vaticano, para onde iam diariamente e lá ficavam o dia inteiro na reunião. Uma manhã, viajaram para Castel Gandolfo, onde o Papa os recebeu. Dr. Gazzinelli disse aos colegas que iria comprar umas medalhinhas. Alguns estranharam e perguntaram: "Você vai comprar medalha, mas para quê? É que muita gente lá no Brasil me pediu, pois a medalha que a gente compra aqui e o Papa benze lá vale o dobro". E, assim, não houve quem não quisesse comprar também.

Ainda em sua sala, outros objetos me chamaram a atenção. Na parede atrás da porta, ressalta-se um cartaz de um mapa metabólico. Ao indagar sobre ele, a conversa fluiu para outros fatos científicos e reflexões sobre a ciência. Dr. Gazzinelli fala sobre o cartaz: "Nos Estados Unidos, eu trabalhava só com biossíntese de proteínas. Mas quando voltei, me falaram que eu teria de dar aula sobre tudo e me pediram para ensinar metabolismo, e eu não sabia por onde começar. Então, peguei o mapa metabólico e passei a levá-lo para as aulas; ele funcionava como um guia. Naquela época eram muitos os estudantes, de modo que eu repetia a mesma aula para seis turmas diferentes. Como a gente ganhava pouco, eu era professor itinerante e saía por aí repetindo a mesma aula em Barbacena, Pouso Alegre, Itajubá, entrava por São Paulo, São José do Rio Preto, depois viajava para o Piauí, sempre levando o mapa metabólico. Em pouco tempo eu já sabia de cor cada detalhe do mapa. Dava a aula indicando para os alunos no mapa: de um lado fica o número e, de outro, a letra. Por exemplo, B4, vocês vão encontrar uma sequiência de reações em cor verde - eu já sabia tudo de cor: trata-se do metabolismo de carboidratos etc. Foi uma época muito interessante. Agente 
viajava muito. No Piauí, por exemplo, em Teresina, eu dava apenas duas aulas à tarde e ficava a manhã inteira sem nada para fazer, isso durante um mês. Então, um dia, perguntei se alguém teria uma planta interessante para que eu testasse seu extrato. Trouxeram-me amostras de uma planta que diziam ser afrodisíaca. Fiz o extrato e pedi que me conseguissem camundongos ou ratos brancos, para fazer a experiência. O meu plano era injetar nos animais o extrato, colocá-los para acasalar e verificar se eles procriavam mais do que os controles. Os estudantes lembraram que na cidade havia uma senhora que criava rato branco. 'Então vamos lá na casa dela', disse eu. Lá ficamos sabendo que ela só poderia nos dar o rato à noite. E a razão era a seguinte: só à noite o rato saía de um buraco dentro de sua própria casa, ela armava uma armadilha e o prendia. Depois, colocava-o em uma gaiola. Mas o animal era uma fera, de modo que não foi possível trabalhar com ele. Solicitei então camundongos aqui de Belo Horizonte, que me foram enviados de avião. Fiz a experiência e nada, a planta não era afrodisíaca coisa nenhuma, era mais folclore".

Pergunto sobre um outro mapa, mais recente, vistoso e intrigante, afixado na parede em frente à porta. Dr. Gazzinelli então me conta que trata-se de um mapa de construção recente, principiado no início dos anos 90 , ou no final dos anos 80 . Os livros antigos ainda não o mostram. Trata-se de um mapa de sinalização que explica o mecanismo de diferenciação celular. É o seguinte: quando uma proteína se liga a receptores na membrana celular, ela dá um sinal de que vai terminar no núcleo e vai desreprimir ${ }^{61}$ o gene para produzir uma proteína nova. A forma como o mapa está sendo construído agora ainda é incompleta, mas ilustrativa de como será no futuro. Dr. Gazzinelli vai apontando e me mostrando as moléculas pequenas, as moléculas grandes e as estruturas que são proteínas ou enzimas. Explica o modo de ativar a proteína, por

\footnotetext{
${ }^{61}$ Retirar ou remover a repressão do estímulo antigênico.
} 
meio da fosforilação. De modo simples, compreendo como, colocando-se fósforo na macro-molécula protéica, uma enzima se torna ativa. E aí, por exemplo, se ela não penetra no núcleo, ao ser fosforilada passa a entrar, desreprimindo alguns genes e fazendo com que um segmento do DNA que não funcionava passe a fabricar proteínas, macromoléculas que dão características à célula ou ao indivíduo. Os elementos do mapa são proteínas, e as conexões são sinais biológicos.

Dr. Gazzinelli afirma que do mapa constam algumas vias de sinalização que serão desenvolvidas nesta primeira década dos anos 2000 , justamente um dos aspectos que ainda precisam ser estudados na área da bioquímica. Pergunto-lhe o que pensa serem os desafios da ciência nos dias de hoje. Em relação às ciências da vida, ele se refere ao sistema nervoso, concluindo que, uma vez desenvolvidos estudos nesta área, nada mais faltará: "Para mim está concluído. O que não se sabe ainda é como o indivíduo tem consciência, como a memória se armazena etc. O resto é a sinalização. Se você determina a sequiência temporal da desrepressão dos genes, você sabe que proteínas serão feitas e suas conseqüências. Eé isso que se está tentando. Já estão decifrando o genoma humano, de modo que só ficam detalhes por descobrir". Sobre o processo da evolução, contou sobre o importante trabalho de um casal de pesquisadores americanos, que viveu nas Ilhas Galápagos e viu a evolução acontecendo. Por causa do clima, aconteceu um processo muito rápido de seleção natural. Em consequiência da severa seca causada pelo El Niño, os tentilhões cujo bico era muito longo sobreviveram e procriaram; e os que tinham bico curto desapareceram, por não serem capazes de retirar o alimento - larvas - dos orifícios das árvores. O casal trabalhou lá durante uns vinte anos e pôde observar esse processo de seleção ocorrer. Falando da área da física, diz que, sobre o universo, há a teoria relativamente plausível do big-bang, uma hipótese cujas conseqüiências se encaixam nos fenômenos observados, embora nunca possa ser demonstrada. Admite que na física existem ainda alguns desafios a superar: "Na verdade, o Einstein sempre tentou, embora sem êxito, conciliar 
a teoria quântica com a teoria da relatividade. Porque na teoria quântica tem-se o princípio da incerteza, a variação das posições das partículas, o que não se concilia com a teoria da relatividade, que pressupõe relações determinadas. A teoria unificada ainda é um problema". E novamente vem à tona o humor satírico do Dr. Gazzinelli: "A propósito, lembro-me de uma história interessante de um físico que foi convidado para fazer uma conferência na Bolsa de Valores, cujos aplicadores estavam interessados em entender um pouco do universo. A pessoa que foi conduzindo o físico para sua apresentação lhe disse: 'Olha, por favor, não vai dizer que o universo vai terminar daqui a cinco bilhões de anos, porque a bolsa pode cair".

Além dessa instigante conversa, Dr. Gazzinelli contou-me as suas histórias.

\section{Memórias da Carreira, do Instituto de ciências Biológivas e do centro de Pesquisas René Rachou}

Quando você me falou do livro, veio-me imediatamente à memória, de um modo geral, a minha carreira, que, aliás, foi toda ela permeada por circunstâncias favoráveis. Que circunstâncias favoreceram minha carreira? Primeiramente, quando cursava o segundo ano de medicina, o Prof. Baeta Viana, nome inesquecível na área de bioquímica, retornara para a Faculdade de Medicina, onde pretendia restaurar o Laboratório. Um colega meu, José Miguel, que já ouvira falar do Prof. Baeta, me convenceu a fazer ciência. $\mathrm{O}$ Baeta é importante, dizia, vamos para o laboratório dele. Fui ver, gostei e lá fiquei. O próprio Zé Miguel acabou não ficando: um ano depois da formatura, por pressão familiar, abandonou o laboratório e foi fazer clínica no interior de São Paulo. Com Baeta Viana, recebi treinamento excepcional. A gente começava calibrando a balança, porque ele não acreditava que ela fosse precisa. Depois, fazíamos o mesmo com a pipeta. Ele não confiava na precisão 
da própria marca da pipeta. E nos obrigava a calibrá-la usando mercúrio, pesando, fazendo a medida exata. Era um treinamento em química analítica, essencial para a investigação na área de bioquímica. Baeta Viana acentuava muito a noção de exatidão na medida, o rigor, a fidelidade, para que os resultados fossem reprodutíveis. Esse treinamento foi muito útil para mim.

Esqueci-me de mencionar um fato anterior de minha vida, também circunstancial: o meu pai adoeceu, ficou tuberculoso, os irmãos se dispersaram e eu fui enviado para o seminário de Diamantina. No seminário, onde há horário para tudo, aprendi a disciplina e o prazer da leitura, o que também foi importante. No seminário a gente tinha horário para leitura, duas horas diariamente. Tomei gosto por ler, aprendi português, latim, o que me ajudou bastante. E ainda aprendi a jogar futebol. Joguei aqui em Belo Horizonte, na várzea. Agora, ciência só fui começar com o Prof. Baeta.

Outra circunstância interessante, que tentarei resumir: depois de formado em medicina, fui fazer estágio no exterior, Estados Unidos, à época do desenvolvimento da biologia molecular, o que foi muito importante. Eu trabalhei num laboratório que estudava biossíntese de proteína. Em 1953, Watson e Crick identificaram a estrutura exata do DNA, sugerindo sua função e o mecanismo de sua duplicação. Até 1950, não existia nada de biossíntese de proteína, a noção de síntese de proteína começou praticamente em fins da década de 40, em 49. Até então, acreditava-se, equivocadamente, que as enzimas proteóliticas que degradam proteínas eram as mesmas que faziam a síntese. As idéias de Watson e Crick estimularam o estudo da biossíntese de proteína e eu fui para o laboratório do Dr. Sherman Dickman, que estava investigando biossíntese de enzimas pancreáticas. Foi em Salt Lake City, Utah, onde havia um bioquímico muito importante na época, Emile Smith, que fez a seqüência primária da papaína. Foi a segunda enzima a ser seqüenciada; a primeira foi a ribonuclease. No departamento de bioquímica da Universidade de Utah, eu estagiei de meados de 1960 a 1962, trabalhando em biossíntese de proteínas. Nessa época surgiram os trabalhos de Monod e Jacob e outros, apresentando os conceitos de gene 
regulador e de RNA mensageiro. Não era conhecido o modo como a mensagem para a fabricação da proteína se transmitia do núcleo para o citoplasma, e a descoberta do RNA mensageiro veio preencher tal lacuna. A mensagem do DNA era transcrita em m-RNA, que no ribossoma era traduzida em proteína. Monod e Jacob ganharam o Prêmio Nobel por sua grande contribuição nessa área. Logo em seguida, surgiu a idéia genial do grupo do Niremberg (era casado com uma brasileira), de decifrar o código genético adicionando o mensageiro poli-U (ácido nucléico formado apenas de ácido uridílico) a um sistema de síntese de proteína in vitro. Ao se obter um polipeptídeo formado por fenilalanina, concluiu-se que o ácido uridílico codificava fenilalanina. Daí em diante foi fácil.

Mas vamos à história do ICB (Instituto de Ciências Biológicas). Sua implantação começou na Escola de Medicina da UFMG, no quarto andar, na avenida Alfredo Balena. Lá foram reunidas todas as bioquímicas da Universidade, e também todas as fisiologias, microbiologias etc., tendo sido o Prof. Cisalpino, se não me engano, o primeiro diretor do ICB. O Prof. Baeta já havia se aposentado, e o chefe da Bioquímica era o Prof. Diniz. Aí vale lembrar um aspecto interessante. Quando mais novo, eu era um tanto agressivo - agressivo com as coisas, não com as pessoas. Depois, com o envelhecimento, a gente vai ficando boba. Nessa época, veio um professor de farmacologia da Universidade de Buffalo - interessante esta relação circunstancial que tenho com Buffalo: ainda agora estamos com um convênio com a Universidade de Buffalo, e mais interessante é que o Dr. Colley, meu colaborador, nasceu lá. Ele costumava dizer assim: "Eu nasci em Buffalo, New York". Mas, como dizia, naquela época veio para a Faculdade de Medicina um professor de farmáacologia - Dr. Edward Bridge - em um programa com a Fundação Rockefeller, para realizar um curso de pedagogia e relações humanas. Eu era jovem e o Prof. Diniz falou assim: "Você é o mais indicado para fazer esse curso, eles estão pedindo para indicar um de cada departamento e eu vou nomear você". Aleguei que não estava interessado, porque o meu negócio era ciência. O Diniz insistiu: "Você tem 
que ir, você é professor assistente, tem que obedecer", e então fui eu. Foi um curso interessantíssimo, que deixou influência muito positiva. Mais tarde, nós aplicamos esse curso em outras universidades, inclusive na USP, o Carlos Diniz e eu. Era todo baseado em dinâmica de grupo, havia um psiquiatra chileno, cujo nome não me recordo, um psicólogo, era multidisciplinar, tinha gente da área clínica, da área básica. Acho que isso teve alguma influência sobre mim, porque aprendi a manipular minha agressividade. Parece-me que foi em 1968 que nós nos mudamos para o prédio do ICB na Pampulha, por aí. Logo em seguida foi instalada a pósgraduação. Eu não sei bem as datas. A Bioquímica foi o primeiro departamento que instalou a pós-graduação no ICB.

\section{A Vinda para o René Rachou}

Comecei a trabalhar com 14 anos na Cidade Industrial, em Contagem. Ia de Belo Horizonte na carroceria de caminhão. Então, costumo dizer: "Quem fez a Cidade Industrial foi o Benedito Valadares e eu. Ele era o governador e eu, o datilógrafo". Depois, vindas as eleições, fiz concurso para o Tribunal Eleitoral, fui ser taquígrafo. Já estudava medicina. Foi no tribunal que eu conheci a minha mulher, Edméa, e me casei. Ela era minha colega, era taquígrafa. Por ter começado cedo, aposentei-me cedo, com 37 anos de serviço e apenas 51 de idade. Aposentei-me como professor da UFMG no dia 28 de fevereiro de 1980 e vim para o Centro de Pesquisas René Rachou em $1^{\circ}$ de março, no dia seguinte. O Naftale Katz e o Zigman Brener me convidaram para ocupar o Laboratório de Sorologia, mas eu só entendia de bioquímica. Então, as circunstâncias me favoreceram mais uma vez. Conhecia um americano que era imunologista e que trabalhava na área de esquistossomose. Eu o encontrava sempre em congressos, e ficamos amigos. Resolvi perguntar-lhe se me ajudaria a montar um laboratório de imunologia aqui, no René Rachou. É o Daniel Colley, você deve conhecê-lo. 
Hoje ele é um dos diretores do Center of Deseases Control (CDC). Na época, ele aceitou o desafio, e juntos elaboramos um projeto para a OMS, que foi aprovado e financiado durante 15 anos. Em razão disso, ele vinha ao nosso laboratório todo ano, de dois a três meses, por cerca de 13 anos. No final da década de 80 obtivemos também um auxilio substancial do National Institutes of Health (NIH). O Dr. Colley trabalhou aqui comigo por uns 15 anos, de 1980 a 1995, mas, ao se transferir da Universidade de Vanderbilt para o $\mathrm{CDC}$, as suas visitas foram rareando, porque já não tinha muito tempo disponível. Mas ele me ajudou muito na instalação deste laboratório. O Rodrigo (Corrêa de Oliveira) veio para o laboratório em 1991, se não me engano. Quando completei 65 anos, acho que foi em 94 ou 95, pedi demissão da chefia, alegando para o Naftale (na época diretor do $\mathrm{CPqRR}$ ) que não queria mais fazer serviços administrativos. Ele, então, indicou o nome do Rodrigo para me substituir na chefia, mas eu continuei trabalhando em pesquisa. Deixei o laboratório praticamente pronto, mas Rodrigo o ampliou bastante, especialmente na área de citocinas, que, aliás, foi introduzida por ele. Recebi um laboratório de sorologia, transformei-o em laboratório de imunologia celular, e o Rodrigo o modernizou. Além disso, vários estudantes de pós-graduação que orientei foram importantes para o desenvolvimento do laboratório. Como meu laboratório estava em contínua atividade, atraía excelentes estudantes, especialmente para o doutorado.

Perguntado sobre uma pesquisa que destacaria em sua trajetória, o Dr. Gazzinelli me contou o processo de uma descoberta sua, um fenômeno muito interessante, como relatado por ele a seguir.

\section{O Segredo da Transformação}

Os anos em que vivi nos Estados Unidos foram muito importantes para minha carreira. Havia diversas publicações de trabalhos com cercárias, mas não com miracídios. Você sabe como se obtinha o miracídio? 
Comprando fezes humanas. Então, entrei em contato com o Pellegrino, que tinha um laboratório muito produtivo na Faculdade de Filosofia e Ciências Humanas (Fafich/UFMG), ainda na rua Carangola. Queria saber como ele obtinha o material. Ele me explicou que era por intermédio de um técnico que trabalhava com ele e que tinha contato com a Polícia Militar. Ele pagava um sargento, que por sua vez obrigava recrutas (alguns dos quais portadores da esquistossomose) a fazer as necessidades em um latão. Agente punha o material num béquer enorme, cobria a parte de baixo com papel alumínio, para escurecê-la, e iluminava a parte de cima. Os miracídios, atraídos pela luz, iam para a parte de cima, descoberta, e eu os retirava com pipetas. Mas, após coletar os miracídios durante um período de três meses, eu os liofilizei, conseguindo juntar apenas um miligrama, o que era insuficiente para os estudos bioquímicos que eu pretendia realizar. Então, resolvi mudar para cercária ${ }^{62}$ e me associei ao Pellegrino. As pessoas diziam que o Pellegrino tinha um cofre cheio de cercária liofilizada. Verdade ou não, ele passou a fornecê- las a mim.

O estudo de bioquímica requeria certa quantidade de material para purificação da enzima em que eu estava interessado. Eram as enzimas proteolíticas da cercária que participam do processo de penetração na pele do hospedeiro. Eu pretendia esclarecer o mecanismo de penetração. Então, propus ao Pellegrino: "Você me dá as cercárias e todo paper que eu publicar terá seu nome como colaborador". Ele aceitou a proposta e passou a me fornecer uma grande quantidade de cercária. Ele conhecia muito de esquistossomose, de modo que a colaboração foi bastante favorável. E há outro caso interessante: certa vez o Pellegrino viajou para um congresso internacional, em Israel, talvez, e deixou ordem com o Lourenço, seu secretário e técnico: "Você não dê cercária para ninguém". Um dia fui lá

\footnotetext{
${ }^{62}$ Cercária é uma forma larvar do Schistosomamansoni que, em ambientes aquáticos, pode penetrar na pele do homem, causando a esquistossomose.
} 
buscar cercária e o Lourenço me disse: "Olha, o Prof. Pellegrino deixou ordem para não fornecer cercária para ninguém". Eu respondi: "Mas para mim ele não iria negar, nós temos uma colaboração". Ele insistiu: "Mas ele deixou ordem, não vou poder fornecê-la". No período em que o Pellegrino esteve fora, escrevi um paper e publiquei sem o nome dele. Algum tempo depois que ele voltou, disse-me: "Eu vi aquele paper publicado e não tem o meu nome". Respondi logo: "Mas, segundo o Lourenço, você havia deixado ordem para para não me fornecer cercárias". Ele: "Ô, Lourenço, vem cá. Quando o Gazzinelli pedir cercária, você entrega todas que tiver!" E nós colaboramos por muitos anos, temos vários trabalhos publicados em colaboração.

Nessa minha trajetória pelo estudo da bioquímica do parasita (Schistosoma mansoni), caracterizamos as enzimas proteolíticas da cercária e investigamos a transformação desta em esquistossomulo (Schitosoma jovem); dos nossos trabalhos, este é o mais citado (Classic Citation). Quem participou desse estudo na época foi o JuarezRamalho Pinto, que estava fazendo tese comigo. Ele já se aposentou, e agora está em Ribeirão Preto. Foi meu primeiro estudante, e o Tomás Aroldo Mota Santos, que foi reitor da UFMG, foi o segundo doutor que orientei.

Eu, o Juarez e o Eurico (Prof. Eurico Alvarenga Figueiredo) queríamos obter esquistossomulos, necessários para estudos bioquímicos, em grande quantidade. Havia um método da Stirewalt, uma pesquisadora coronel do Exército americano que produzia muito. Estive lá no seu laboratório em Washington. A técnica era a seguinte: retirava-se a pele do camundongo, limpava-se e tirava-se todo o seu pêlo. Colocava-se então essa pele sobre um frasco contendo meio apropriado e com dupla parede para fazer circular água morna a 37 graus. Em cima da pele era adaptado outro frasco, onde se colocava a água contendo milhares de cercárias. A cercária, então, passava através da pele e caía no frasco inferior, contendo o meio, já como esquistossomulo. A cercária, da cabeça à cauda, que é bifurcada, tem de 100 a 150 micra; ao atravessar a pele do camundongo, um pouco mais espessa, 
ela perdia a cauda e caía no meio de cultura como esquistossomulo. Mas, usando esse método, a quantidade obtida ainda era pequena e, além disso, a cercária, ao atravessar a pele, levava junto material desta, dificultando a análise bioquímica. Então, nós procuramos fazer um sistema limpo, sem contaminação. Aié que nós descobrimos que bastava tirar a cauda da cercária que ela se transformava em esquistossomulo. Foi mesmo um processo de observação. Surgiu a idéia: vamos tirar essa cauda - não sei quem teve a idéia original, se eu ou o estudante, o certo é que fizemos juntos. Removíamos as caudas no vórtex. As cercárias eram colocadas em um tubo de centrífuga contendo meio de cultura. $\mathrm{O}$ tubo era colocado no vórtex, o líquido se mexia e a cauda saía devido à vibração - o vórtex vibrava de vinte a trinta segundos.

A descoberta foi muito interessante pela sua simplicidade. O modo como a cercária penetrava no hospedeiro já havia sido descrito pela Stirewalt. A cercária tem glândulas que secretam polissacárideos e glicoproteínas que a fazem grudar na pele; em seguida ela se agita violentamente, perde a cauda e aí penetra. $\mathrm{O}$ que nós fizemos foi arrancar a cauda utilizando a vibração. Quando se arranca a cauda, pode-se saber se ela se transformou ou não em esquistossomulo do seguinte modo: a cercária vive em água; depois de transformada em esquistossomulo, se você colocá-la na água, ela morre. É tudo muito simples: retirávamos a cauda das cercárias e incubávamos seus corpos em meio de cultura, por alguns minutos. Em seguida, uma amostra contendo alguns corpos era transferida para a água; se os corpos mor ressem, podíamos concluir que a transformação havia ocorrido, com certeza. A transformação altera a permeabilidade, deixando penetrar a água através da membrana do esquistossomulo, e por esta razão ele só sobrevive em meio salino. A cercária possui um glicocálice que ela perde com a transformação, além da cauda e das glândulas pré e pós-acetabulares. São glândulas enzimáticas, têm atividade proteolítica.

Esta foi uma descoberta interessante, e é o nosso trabalho mais citado na literatura. Queríamos uma grande quantidade de cercária e de vermes 
jovens, para fazer análises bioquímicas e depois comparar uma forma com a outra. O que pretendíamos saber até hoje não se sabe - não se sabe porque não há interesse. Na época não estava ainda estabelecida claramente a noção de desregulação de genes, ela estava apenas surgindo.Jacob e Monod haviam proposto a distinção entre genes reguladores e estruturais. Hoje, sabe-se que deve ocorrer durante a transformação uma desrepressão de genes, surgindo proteínas novas que vão imprimindo características nos esquistossomulos. Mas ainda não se estudou, em detalhes, essa transformação. Nós chegamos a estudar até a penetração de aminoácidos no esquistossomulo. Certa ocasião, o Pellegrino quis fazer cercária radioativa com aminoácido marcado no carbono 14 ; fez várias experiências mas não conseguiu, porque o glicocálice impede sua penetração através da membrana. A cercária sobrevive e se movimenta na água, para cima e para baixo, às custas de glicogênio acumulado. Já o esquistossomulo necessita de nutrientes do meio, ou seja, à medida que o verme vai se desenvolvendo, há captação de aminoácidos e outros nutrientes do meio, iniciando-se a síntese de material necessário para o seu desenvolvimento. Como é feita essa regulação, até hoje não se sabe. Agora é que estão estudando os genes do parasita, seqüenciando todo o genoma e, assim, poderão chegar a entender melhor o fenômeno. $\mathrm{Na}$ época, não era possível.

Além dessa interessante história, perguntei ao Dr. Gazzinelli sobre descobertas importantes realizadas no CPqRR. Ele então falou sobre a descoberta, pelos pesquisadores do René Rachou, Dr. Zigman Brener e Dra. Antoniana Krettli, do anticorpo lítico, assim como sobre alguns trabalhos de seu próprio laboratório. Segue seu relato sobre tais descobertas. 


\section{Sobre a Descoberta do Anticorpo Lítico e Outras Evidências em relação à Doença de Chagas}

Antes de relatar a descoberta, é preciso esclarecer que o anticorpo lítico está especificamente relacionado à doença de Chagas. O protozoário Trypanosoma cruzi, causador da doença, apresenta diversas formas em seu desenvolvimento, que são diferentes no barbeiro, inseto vetor da parasitose, e no homem. Assim, na história serão mencionadas algumas dessas formas, como a tripomastigota, que é o estágio em que o parasita se encontra na circulação sangüínea do ser humano.

Como relata Dr. Gazzinelli, o que a Dra. Antoniana e o Dr. Zigman descobriram é que existia, além dos anticorpos tradicionais, usados na sorologia, um anticorpo dirigido estritamente contra a forma tripomastigota; era um marcador específico. Eles constataram que esse anticorpo protegia o indivíduo porque era capaz de lisar ${ }^{63}$ a forma tripomastigota sangǘnea, sendo chamado de anticorpo protetor. Tinham, então, duas funções: lisar o tripomastigota e estabelecer o equilíbrio hospedeiro-parasita.

Quando se tem a forma aguda de Chagas, encontra-se alto número de tripanossomas no sangue, mas essa quantidade decai rapidamente, mantendo-se escassa a parasitemia pelo resto da vida do indivíduo. Provakelmente, um dos componentes que mantêm esse número baixo é o anticorpo lítico, que destrói o tripomastigota do sangue, controlando a parasitemia, embora não se saiba, quantitativamente, qual seria sua importância. Cabe aqui explicar a relação entre a detecção dos anticorpos nos exames sorológicos e a evidência de cura dôs portadores da doença de Chagas. Por meio desses exames, há dificuldade para se determinar se o indivíduo está curado ou não, pois mesmo naqueles aparentemente curados

${ }^{63}$ Lisar: definir: 
ainda podem ser encontrados os anticorpos convencionais. Esses indivíduos que possuem os anticorpos convencionais no soro mas não têm o anticorpo lítico que aparentemente indica a presença do parasita foram denominados de dissociados. Quer dizer: se o indivíduo tem anticorpo lítico circulante, tem a doença ativa. O Trypanosoma cruzi, na forma tripomastigota, está lá, induzindo a síntese do anticorpo. Quando os anticorpos convencionais e o lítico não são detectados no soro de pacientes tratados, estes certamente estão curados. Como se vê, a descoberta do anticorpo lítico melhorou sensivelmente o diagnóstico de cura, tornando-se importante fator indicador da condição da doença. Após quimioterapia - na doença de Chagas não há cura espontânea -, os indivíduos dissociados (anticorpos convencionais positivos e lítico negativo) estão provavelmente caminhando para a cura. $O$ anticorpo lítico, além de indicar infecção ativa, é também protetor. In virro, o lítico provoca a lise do Trypanosomacruzi. É induzido por uma proteína da membrana do tripomastigota sangüíneo e é muito instável e de difícil obtenção. Uma pesquisadora americana cujo nome não me recordo já extraiu e purificou essa proteína, e penso até que já produziu a proteína recombinante.

A for ma clínica de chagásico sem sintoma é chamada de indeterminada. A maioria dos indivíduos infectados apresenta a forma indeterminada. Como disse, na forma aguda o nível de tripomastigota sangüíneo está bem elevado. Em seguida o paciente entra numa fase em que o parasita desaparece no sangue - forma indeterminada. Esta é uma questão ainda não esclarecida, isto é, por que algumas pessoas se mantêm nessa fase indeterminada enquanto outras desenvolvem manifestações mais severas da doença, como a cardiopatia (de 20 a 30\%) ou o megacólon (cerca de $10 \%)$, ou mesmo ambas. Mas a maioria, cerca de $65 \%$, permanece na forma indeterminada.

É interessante que não se tenha tentado fazer a vacina contra a doença de Chagas. Não vejo muito investimento nessa área, como ocorre com a leishmaniose e a esquistossomose. Contra a malária, por exemplo, a literatura 
relata várias vacinas ditas protetoras em seres humanos, quando testadas em laboratório. Entretanto, quando os testes foram realizados em área endêmica, a vacina não funcionou, não protegeu. Chagas é aparentemente mais complicado. Talvez, uma das razões para não se ter investido em vacina contra Chagas seja a influência da idéia de que a doença seria resultante de reação auto-imune que poderia ser induzida mesmo na ausência do tripanossoma vivo, noção que agora está sendo descartada.

O Antônio Teixeira, da UnB, foi um pessoa importante naárea de Chagas, pois, quando trabalhou nos Estados Unidos, foi um dos primeiros pesquisadores a enfatizar a hipótese de que Chagas seria uma doença autoimune. $\mathrm{Na}$ época, também o L. Hudson, amigo do Zigman, que esteve aqui com a gente no laboratório, exerceu também grande influência no estabelecimento da idéia de que Chagas seria uma doença auto-imune. Em geral, quando o linfócito se desenvolve, diz-se que ele é educado no timo. Essa educação consiste no seguinte: todos aqueles linfócitos que têm a capacidade de agredir células do próprio corpo são eliminados por apoptose, ficando apenas aqueles que agridem organismos ou antígenos estranhos, que vêm de fora. Então, teoricamente, você não teria linfócitos que se autoagridem. Mas acontece que, por razões ainda não muito claras - existem agora diversos mecanismos para explicar a auto-imunidade -, o sistema imune de alguns indivíduos se agride e produz doença, como a diabetes ou a artrite reumatóide. São auto-agressões.

No caso de Chagas crônico, como não se encontra o tripanossoma após exames repetidos de xenodiagnóstico ou várias hemoculturas, procurou-se explicar a extensão e intensidade das lesões do miocárdio por meio da auto-imunidade. Uma extensa destruição do miocárdio associada à escassa parasitemia acabou por induzir essa teoria. A indução da auto-imunidade em Chagas, entretanto, precisa ser esclarecida. Elizabeth Jones, uma estudante americana que, trazida pelo Colley e trabalhando em colaboração com um grupo de Uberaba, estagiou em nosso laboratório, demonstrou, em fragmentos do coração obtidos em autópsia de pacientes falecidos com 
doença de Chagas, que nas lesões do miocárdio onde não se encontrava o tripanossoma era possível detectar o seu DNA por meio de PCR. ${ }^{63}$ Quer dizer: onde havia lesão no miocárdio sempre se encontrava o tripanossoma ou o seu DNA. Onde não havia lesão no miocárdio, a reação para o DNA era negativa. Esse achado foi confirmado por uma pesquisadora paulista de origem japonesa que trabalhava com o Kalil, Dra. Higushi, utilizandose de biópsia do miocárdio de chagásicos. Ela mostrou, em sua tese, que nas lesões do miocárdio sempre se encontrava o tripanossoma. Então ficou estabelecido o seguinte: não existe lesão no coração sem a presença do tripanossoma. A agressão auto-imune seria uma conseqüência dependente da presença do parasita. Débora Reis, atualmente na Morfologia da UFMG, quando fazia o seu doutoramento conosco demonstrou, em colaboração com o Dr. McCurley, da Universidade de Vanderbilt, em um programa de bolsa-sanduíche, que nas lesões do miocárdio existiam muito mais linfócitos $\mathrm{CD} 8$ ativados do que $\mathrm{CD} 4$, sugerindo que linfócitos $\mathrm{CD} 8$ estariam envolvidos na inflamação e lesão do miocárdio. Pode-se concluir que as lesões do miocárdio dependem da presença do parasita, embora não se possa descartar a associação de lesões auto-imunes induzidas por CD8+. É um campo de trabalho que ainda requer muita investigação, e vários aspectos continuam a ser estudados no nosso laboratório e em outros da Fiocruz e de outras instituições.

Atualmente o trabalho do Dr. Gazzinelli se divide entre o René Rachou e a Santa Casa. No René Rachou ele coordena um projeto do Pronex com 14 subprojetos - todos da área de imunologia de doenças parasitárias - cujos pesquisadores principais são de diversas unidades: da Universidade Norte Fluminense, do Departamento de Bioquímica Médica da UFRJ, do ICB da UFMG, das escolas de Enfermagem e Medicina da UFMG, da Universidade de Ouro Preto e do CPqRR. Na Santa Casa, integra, com

${ }^{63}$ PCR: Polymerase Chain Reaction, técnica de biologia molecular. 
outros pesquisadores de ciências básicas (imunologia, parasitologia, epidemiologia e biologia molecular), o Comitê de Pós-Graduação, o qual, coordenado por um clínico, tem como missão desenvolver pós-graduação para médicos na área de clínica médica/biomedicina, com ênfase especial na ciência médica moderna. Para desenvolver projetos científicos, contarão com um laboratório multidisciplinar, uma enfermaria voltada para a pesquisa clínica e um biotério. O curso já foi aprovado pela Capes e já conta com dez alunos matriculados. 


\section{Giovanni Gazzinelli ${ }^{64}$}

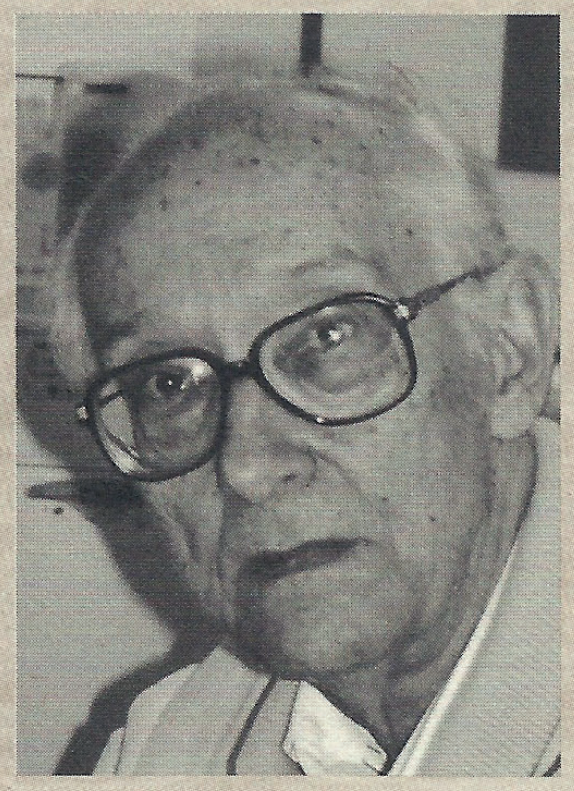

Dr. Gazzinelli nasceu em Araçuaí, Minas Gerais, em 6 de setembro de 1927. Formou-se em medicina pela UFMG em 1955, onde também doutorou-se em 1965, defendendo a tese intitulada complexo proteolítico das Glândulas Acetabulares do Schistosoma mansoni. Em 1972 obteve um segundo título de doutor, desta vez em bioquímica, com a tese Enzimas Proteolíticas da Cercária do Schistosoma mansoni: purificação, propriedades, função. Desde cedo iniciou-se na carreira científica, tendo sido bolsista do Departamento de Bioquímica da UFMG de 1956 a 1959, sob orientação do Professor Baeta Viana. Fez pós-graduação no Departamento de Bioquímica da Tulane University (Nova Orleans, EUA) de 1960 a 1961, e no Departamento de Bioquímica da Utah University (Salt Lake City, EUA), de julho de 1961 a dezembro de 1962. Tornou-se professor do Departamento de Bioquímica da UFMG em 1962, chegando a titular em 1975. Orientou diversas teses pelos cursos de pós-graduação dos departamentos de Bioquímica e Parasitologia da UFMC e de Imunologia da Escola Paulista de Medicina e do IOC. Em 1980 aposentou-se da universidade e foi contratado como pesquisador titular pelo CPqRR/ Fiocruz, onde foi chefe de laboratório até 1995. Em 1997, aposentou-se compulsoriamente da Fiocruz. Atualmente é bolsista do CNPq lotado no CPQRR.

\footnotetext{
64 Texto extraído de seu curriculum vitae.
} 
Exerce também, desde 1998, as funções de membro do comitê de Pós-Graduação em Clínica Médica/ Biomedicina da Santa Casa de Misericórdia de Belo Horizonte. Recebeu diversos prêmios: Prêmio Silva Lima, concedido pela Academia Brasileira de Medicina em 1977; Medalha Carlos Chagas concedida pelo governo do estado de Minas Gerais (1991); Medalha da Inconfidência, do governo do estado de Minas Gerais (1994); e Comenda da ordem Nacional do Mérito Científico, da Presidência da República (1998). É membro titular da Academia Brasileira de Ciências, professor emérito da UFMG (1996) e membro honorário da American Society of Tropical Medicine and Hygiene (1996). Em 1997 recebeu o título de professor honoris causa da Univale (Universidade Vale Rio Doce) e o Diploma de Honra ao Mérito do Centro de Pesquisas René Rachou. Foi presidente da Sociedade Brasileira de Bioquímica no período 1980 1981 e conselheiro da SBPC. Trabalnou como temporary adviser da OMS no período 1982-1983 e no Comitê Assessor do Conselho Nacional de Desenvolvimento Científico e Tecnológico nos períodos 1985-1986 e 1989. Foi vice-presidente da Associação Brasileira de Imunologia de 1987 a 1989 e coordenador de Pós-Graduação da Capes na área de Ciências Biológicas III (Imunologia, Microbiologia Parasitologia) de 1977 a 1999. É membro da American Association of Immunologist desde 1991. Publicou mais de 150 trabalnos em revistas científicas nacionais e internacionais, assim como capítulos de livros e textos didáticos de divulgação do seu trabalho em jornais e revistas brasileiros. 